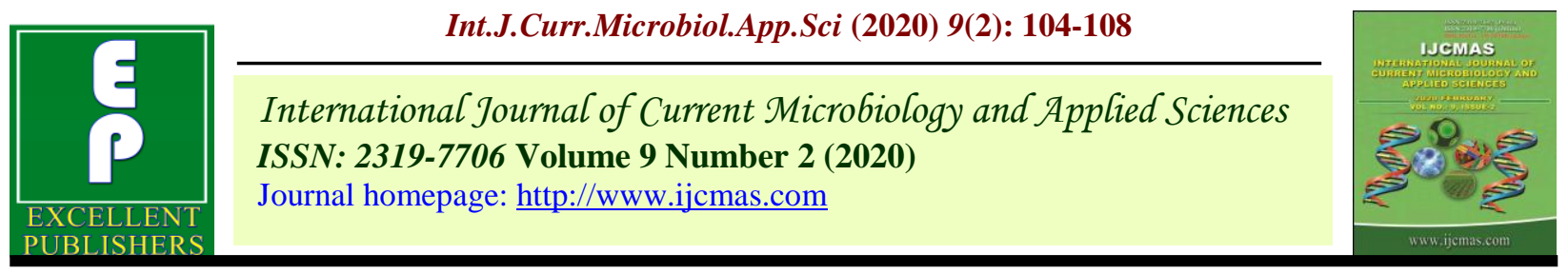

Original Research Article

https://doi.org/10.20546/ijcmas.2020.902.013

\title{
Adoption of Vermicompost Technology for Livelihood Improvement of Farmers in Sivasagar District of Assam, India
}

\author{
Arundhati Bordoloi $^{1^{*}}$, Rupjyoti Bora ${ }^{2}$ and Prodip Handique ${ }^{1}$ \\ ${ }^{1}$ Krishi Vigyan Kendra, Sivasagar, Assam Agricultural University, \\ Rohdoi-785687, Sivasagar, India \\ ${ }^{2}$ Directorate of Extension Education, Assam Agricultural University, India \\ *Corresponding author
}

\begin{tabular}{|l|}
\hline Ke y w or d s \\
Adoption, \\
Vermicompost, \\
$\begin{array}{l}\text { Farmer, FLD, KVK, } \\
\text { Popularization }\end{array}$ \\
\hline Article Info \\
\hline $\begin{array}{l}\text { Accepted: } \\
\text { 05 January } 2020 \\
\text { Available Online: } \\
\text { 10 February } 2020\end{array}$ \\
\hline
\end{tabular}

\section{A B S T R A C T}

The awareness for vermicompost production for soil health as well as for entrepreneurship development was created among the rural population of Sivasagar district of Assam by Krishi Vigyan Kendra, Sivasagar through Front Line Demonstration programmes. The FLD programmes were conducted during August, 2012 to September, 2018 and the study was conducted during April 2019 to August 2019. The study was conducted on the beneficiaries of FLD programmes and total 100 farmers were selected randomly. The research design followed in the study was survey research method and the data collected by pretested well structure interview schedule. It is clear from the results that female farmers were more interested to adopt vermicompost (78.4\%) as compared to male farmers $(55 . .6 \%)$. The independent variables like gender, age, education, caste, income and land holding of farmers were the important variables for adoption of vermicompost technology. The study indicates that KVK, Sivasagar was able to motivate the middle aged and middle school pass farmers to adopt the technology with the highest benefit-cost ratio (3.52). Therefore, there is need to popularize vermicompost technology among young farmers and SC \& ST community for greater upliftment of farming community.

\section{Introduction}

Vermicompost is highly nutritive and a powerful plant growth promoter and protector. Vermicomposting is a modified and specialized method of composting where earthworms are used to eat and digest farm waste and turn into high quality compost in two months or less (Patel et al., 2015). The fine granular peat like end product, vermicompost that is produced is reported to contain elevated levels of nitrogen, phosphorus and potassium (NPK) in available form, micronutrients, microflora and enzymes (Edward, 2004; Ansari, 2011) as compared to the traditional compost. Secretions of earthworm that are in vermicompost serve as plant growth stimulating factor (Galli et al., 
1990). Because of this, the vermicompost when applied or supplemented in the soil, it improves crop growth and yield (Zaller, 2007, Joyakumar et al., 2011). In addition, vermicompost produced by the joint action of earthworms and microbes, contains nutrients in available form with increased microbial activities (Aira et al., 2007). Vermicompost rich in humus provide the ability to glue clay, silt and sand particles together enhancing the texture and structure of soil and preventing soil erosion (Sreedevi and Hanchinal, 2017). The vermiwash can also be used as spray on crops. Various economic uses can be obtained from organic waste through vermicomposting. As the cost of production is also very less, farmers can easily produce it.

To popularise the vermicompost process among the small and marginal farmers of Sivasagar district; KVK, Sivasagar created awareness among the farmers through Front line demonstration and training to transfer the vermicompost production technology with low cost structures. The FLD programmes were conducted during August, 2012 to September, 2018 and the study was conducted during April 2019 to August 2019. The purpose of the study was to identify the adoption percentage of beneficiaries and its distribution among the different independent variable selected for the study.

\section{Materials and Methods}

The study on adoption percentage was conducted on the respondent of Sivasagar district, who practiced FLD programme imparted by Krishi Vigyan Kendra, Sivasagar from 2012-13 to 2018-19. The research design followed in the study was survey research method and the data collected by pretested well structure interview schedule. Demonstration and low cost production system techniques were used to motivate the farmers. Front Line Demonstrations (FLD) were conducted by KVK, Sivasagar in a systematic way on farmer's field to show the worth of vermicomposting technology and to convince the farmers to adopt the technology for better soil health as well as better livelihood of the farmers. Under FLD programme, low cost thermo Cole box and silpaulin plastic bags along with earthworms were distributed. A total of 100 beneficiaries were selected randomly for the study, thus constituting the total sample size of 100 respondents. The dependent variable of this study was adoption and independent variables were gender, age, education, caste, income and land holding of farmers. Adoption percentage of each category calculated as:

Adoption percentage $=$

Number of respondent adopted the technology X 100

Number of respondent participated

\section{Results and Discussion}

It was shown from the investigation that a majority of the respondent participated in vermicompost Front Line Demonstration were male farmers $(63 \%)$ followed by female farmer $(37 \%)$ in Table no 1 . But after the demonstration, it is found that majority percentage of respondent adopted vermicompost were female $(78.4 \%)$ followed by male farmer $(55.6 \%)$. The results showed that female beneficiaries of Sivasagar district were more motivated for vermicomposting than the male farmers. This result contradicts the results of Das et al., (2016) where adoption percentage was found maximum with male farmers. It was also found from the survey that majority of farmers from the age group 35 yrs to 50 years participated in the FLD programmes (49\%) and adopted the technology $(73.5 \%)$ followed by the age group 25 years 35 years $(70.4 \%)$. this results showed that the farmers group belonging to the age group 35 years to 50 years were more concerned about the extra earning. Increased 
financial burden may be the reason for adoption of vermicompost of this age group. From the study, it was found that beneficiaries under the category middle school pass adopted the technology highest
(70\%) followed by high school category (65.8\%) compared to other education level whereas the maximum participation was from the high school category (38\%).

Table.1 Adoption percentage of respondent with different independent variable

\begin{tabular}{|c|c|c|c|c|c|}
\hline SI no & Variable & $\begin{array}{l}\text { No of } \\
\text { participant }\end{array}$ & $\begin{array}{l}\text { No of } \\
\text { adopted }\end{array}$ & $\begin{array}{l}\text { Participant } \\
\%\end{array}$ & $\begin{array}{l}\text { Adoption } \\
\%\end{array}$ \\
\hline $\mathbf{A}$ & Gender & & & & \\
\hline 1 & Male & 63 & 35 & 63.0 & 55.6 \\
\hline 2 & Female & 37 & 29 & 37.0 & 78.4 \\
\hline B & Age & & & & \\
\hline 1 & $18 \mathrm{yrs}$ to $<25 \mathrm{yrs}$ & 21 & 8 & 21.0 & 38.1 \\
\hline 2 & $25 \mathrm{yrs}$ to $<35 \mathrm{yrs}$ & 27 & 19 & 27.0 & 70.4 \\
\hline 3 & $35 \mathrm{yrs}$ to $<50 \mathrm{yrs}$ & 49 & 36 & 49.0 & 73.5 \\
\hline 4 & $>50 \mathrm{yrs}$ & 3 & 1 & 3.0 & 33.3 \\
\hline C & Educational level & & & & \\
\hline 1 & Illiterate & - & - & - & - \\
\hline 2 & Can read only & - & - & - & - \\
\hline 3 & Can read and write & 3 & 1 & 3.0 & 33.3 \\
\hline 4 & Primary school & 14 & 8 & 14.0 & 57.1 \\
\hline 5 & Middle School & 30 & 21 & 30.0 & 70.0 \\
\hline 6 & High School & 38 & 25 & 38.0 & 65.8 \\
\hline 7 & Graduate and above & 15 & 9 & 15.0 & 60.0 \\
\hline D & Caste & & & & \\
\hline $\mathbf{1}$ & General & 18 & 9 & 18.0 & 50.0 \\
\hline 2 & $\mathrm{SC}$ & 27 & 17 & 27.0 & 63.0 \\
\hline 3 & ST & 13 & 8 & 13.0 & 61.5 \\
\hline 4 & $\mathrm{OBC}$ & 42 & 30 & 42.0 & 71.4 \\
\hline $\mathbf{E}$ & Annual income level & & & & \\
\hline 1 & Less than Rs 30,000 & 5 & 2 & 5.0 & 40.0 \\
\hline 2 & Rs. 30,001 to 60,000 & 17 & 12 & 17.0 & 70.6 \\
\hline 3 & Rs. 60,001 to $1,00,00$ & 36 & 27 & 36.0 & 75.0 \\
\hline 4 & Rs. $1,00,001$ to $2,00,000$ & 28 & 16 & 28.0 & 57.1 \\
\hline 5 & Rs. $2,00,001$ to $3,00,000$ & 9 & 4 & 9.0 & 44.4 \\
\hline 6 & More than Rs. $3,00,000$ & 5 & 3 & 5.0 & 60.0 \\
\hline $\mathbf{F}$ & Land holding & & & & \\
\hline 1 & $<0.5$ ha & 32 & 21 & 32.0 & 65.6 \\
\hline 2 & 0.5 ha to 2 ha & 43 & 32 & 43.0 & 74.4 \\
\hline 3 & $>2 \mathrm{ha}$ & 25 & 11 & 25.0 & 44.0 \\
\hline
\end{tabular}


Table.2 Adoption percentage of vermicompost production

\begin{tabular}{|l|l|l|l|}
\hline SI no & $\begin{array}{l}\text { Total no. of respondent adopted } \\
\text { vermicomposting }\end{array}$ & $\begin{array}{l}\text { Total no. of } \\
\text { respondent } \\
\text { participated }\end{array}$ & Adoption percentage \\
\hline $\mathbf{1}$ & 64 & 100 & $64 \%$ \\
\hline
\end{tabular}

Table.3 Economics of Low cost and concrete vermicomposting tanks

\begin{tabular}{|l|l|l|l|l|}
\hline Type of tank & $\begin{array}{l}\text { Cost of } \\
\text { Production }\end{array}$ & $\begin{array}{l}\text { Gross return } \\
(\text { Rs) }\end{array}$ & Net return (Rs) & B:C ratio \\
\hline Thermocol box & 170 & 600 & 430 & 3.52 \\
\hline Silpaulin bag & 5000 & 17500 & 13,500 & 3.5 \\
\hline Concrete tank & 21000 & 22500 & 1500 & $*$ \\
\hline & 7000 & 21300 & 14,300 & $* * 3.04$ \\
\hline$* 1^{\text {st }}$ year; $* * 2^{\text {nd }}$ year & & & & \\
\hline
\end{tabular}

The myth about the education level may be the reason for such adoption percentage. Highest participation was observed among the farmers of OBC category (42\%) and adopted as well $(71.4 \%)$ followed by the farmers of SC category $(63 \%)$. As Sivasagar district is dominated by OBC population, so maximum adoption was observed among this category. With the independent variable income, maximum adoption was found among the farmers of income group Rs 60,000 to Rs. $1,00,000(75 \%)$, followed by the income group Rs.30,000 to Rs. 60,000 (70.6\%) where maximum participation was observed among the farmers of income group Rs 60,000 to Rs. $1,00,000(36 \%)$ followed by income group Rs. $1,00,001$ to $2,00,000$. Farmers group having land holding between $0.5 \mathrm{~h}$ to $2 \mathrm{ha} \mathrm{had}$ highest participation percentage (43\%)and showed the highest adoption percentage (74.4\%) followed by the group of farmers having land holding $<0.5$ ha $(65.6 \%)$ and land holding $>2$ ha (44\%).

It was found from the investigation (Table 2) that overall percentage of adoption of vermicompost production was $64 \%$. Out of 100 respondents, 64 nos of farmers adopted the technology for upliftment of their socio economic condition. These findings are supported by various workers (Das et al., 2016, Aski and Hirevenkanagoudar, 2010). Table no 3 describes the economic benefit of low cost vermicompost units in the form of benefit cost ratio. The benefit cost ratio (3.52) was recorded highest in thermocol box units followed by production in silpaulin plastic bags (3.5). Vermicompost produced in concrete thanks in first year could not give any benefit as the costs of construction of tank were too high. From $2^{\text {nd }}$ year onwards benefit cost ratio was recorded as 3.04.

From the above result, it could be concluded that female farmers were more interested to adopt vermicompost as compared to male farmers. The independent variables like gender, age, education, caste, income and land holding of farmers were the important variables for adoption of vermicompost technology. The study indicates that KVK, Sivasagar was able to motivate the middle aged and middle school pass farmers. Therefore, there is need to popularize vermicompost technology among young farmers and SC \& ST community for greater up liftment of farming community. 


\section{References}

Aira, M., Monroy, F., and Dom'inguez, J., 2007. Earthworms strongly modify microbial biomass and activity triggering enzymatic activities during vermicomposting independently of the application rates of pig slurry. Science of the Total Environment 385(1-3) 252-261.

Ansari, A. A., 2011. Worm powered environmental biotechnology in organic waste management. International Journal of Soil Science. 6, (1), 25-30.

Aski, S. G., Hirevenkanagoudar., 2010. Extent of adoption of vermicompost practices by the KVK trained farmers . Asian Sciences 5(2). 85-88.

Das, G., Sarkar, S., Das, S. K., and Biswas, S. 2016. Adoption of vermicompost production with respect some socioeconomic variable. International Journal of Agricultural Sciences. 8(4), 14781480.

Edwards, C. A., and Arancon, N.Q., 2004. The use of earthworms in the breakdown of organic wastes to produce vermicomposts and animal feed protein. In: Edwards C.A. (Ed), Earthworm
Ecology, second ed. CRC Press, Boca Raton, Fla, USA, 345-438.

Galli, E., Tomati, V., Grappelli, A. and de Lene, G., 1990. Effect of earthworm cast on protein synthesis in Agaricus bisporus. Biol. Fert. Soil. 9, 1-2.

Jayakumar, M., Sivakami, T., Ambika, D., and Karmegam, N., 2011. Effect of turkey litter (Meleagris gallopavo L.) vermicompost on growth and yield characteristics of paddy, Oryza sativa (ADT-37). African Journal of Biotechnology. 10(68), 15295-15304.

Patel, R. N., Prajapati, M. R., and Patel, V. T. 2015. Adoption behaviour of Tribal farmers for vermicompost technology. Gujral Journal of Extension Education 26(1), 65-66.

Shridevi, A., Sankaratti, and Hanchilal, S. N. 2017. Adoption of vermicomposting technology by

farmers of Gulbarga district in Karnataka. Agriculture Update 12(4), 639-642.

Zaller, J. G., 2007. Vermicompost as a substitute for peat in potting media: effects on germination, biomass allocation, yields and fruit quality of three tomato varieties. Scientia Horticulturae. 112(2), 191-199.

\section{How to cite this article:}

Arundhati Bordoloi, Rupjyoti Bora and Prodip Handique. 2020. Adoption of Vermicompost technology for livelihood improvement of farmers in Sivasagar district of Assam, India. Int.J.Curr.Microbiol.App.Sci. 9(02): 104-108. doi: https://doi.org/10.20546/ijcmas.2020.902.013 